\title{
Influence of Socio-Economic Change on Marriage Norms in the Yoruba Soiety, in Southwest Nigeria

\author{
Odejobi Cecilia Omobola, Ph.D
}

\author{
Institute of Education, Faculty of Education \\ Obafemi Awolowo University, Ile-Ife, Osun State, Nigeria
}

Doi:10.5901/ajis.2013.v2n3p139

\begin{abstract}
Marriage is a social institution that unites people in a special form of mutual dependence for the purpose of founding and maintaining a family. This article therefore examines the influences of socio-economic change on marriage norms in Yoruba society. The various steps in Yoruba traditional marriage norm were examined and it was discovered that socio-economic change has affected all the cultural norms associated with Yoruba traditional marriage.
\end{abstract}

Keywords: Marriage, social institution, socio-economic, family, Yoruba tradition

\section{Introduction}

The study looks at the influence of marriage. It was conducted in the context of socio-economic change. Socio-economic change refers to any change that occurs within the social and economic structures of a given society (Ngwa, 2003). Changes can result from endogenous forces (forces within the society) as well as from exogenous forces (forces from outside the society) depending on where the change agent comes from. Changes do not occur quickly, but when they occur they change the ecological order, the system of stratification and the social institution of the entire societies.

Social change according to Al-Naser (1996) refers to variations in the ecological ordering of population and communities; in patterns of roles and social interactions; in the structures and functioning of institutions; and in the culture of the societies. Norms are the agreed-upon expectations and rules by which a culture guides the behaviour of its members in any given situation. Of course, norms vary widely across cultural groups (CliffsNotes.com. (2010).

Culture consists of the beliefs, behaviors, objects, and other characteristics common to the members of a particular group or society. Through culture, people and groups define themselves, conform to society's shared values, and contribute to society. Thus, culture includes many societal aspects such as language, customs, values, norms, mores, rules, tools, technologies, products, organizations, and institutions (CliffsNotes.com., 2010). In Yoruba culture, the well being of a marriage is the responsibility of both parties (Popoola \& Oyesanya, 2008). Ultimately, in Yoruba culture, marriage is not the sole responsibility of the couple but that of the communities because it is the joining of two or more families.

\section{Yoruba Traditional Marriage}

The traditional marriage of the Yoruba is an essential institution in their culture. Marriage for the Yoruba man or woman is a necessity. It is a social union or legal contract between individuals that creates kinship in Yoruba culture. It is an institution in which interpersonal relationships, usually intimate and sexual, are acknowledged in a variety of ways, depending on the culture or subculture in which it is found. In the institutional families, marriage is a functional partnership rather than a romantic relationship. For a man or a woman who is matured enough to get married and still remain single is against the norms of the Yoruba. Men get married even when they are impotent in order to save either their immediate relatives, as well as to get someone to look after their domestic establishment (Fadipe, 1970).

The marriage ceremony in the Yoruba culture like other West African countries is always a glamorous affair depending on how wealthy either of the two families involved is. Foods are always in surplus with palm wine, music is always in excess and fun fair will fill the atmosphere both in the young man's house and the ladies' house (Moshood, 2011). The following steps are involved in the Yoruba traditional marriage and they all take place in the bride father's house except the investigation or inquiry meant to find out the outcome of the union. 


\section{The Search for Spouse}

Traditional marriage is solely a family affair. It was the responsibility of the father to look for a spouse for his male child (Moshood, 2011). Once a boy's parents found a girl he will make known his intention to the parents of the girl and start acting like an in-law to the girl's parent and family. Some parents make requests right from pregnancy stage that if a particular woman whom they like is pregnant especially a friend's wife, delivered a female child they would marry her for their son.

As soon as the agreement has been reached between the two families involved, the family of the young boy will begin to render services like free farming work for the family of the girl. On the other hand, when a young man of marriageable age sees a lady he likes, he doesn't go directly to the lady, he engages the services of an intermediary, alarina, who mediates between him and the lady. This mediator does all the necessary underground work for this young man by stylishly introducing him to the lady even when the man is not there and appraising some good qualities of the man to stir up the man's interest in the heart of the lady. By the time the intermediary, alarina, introduces the young man to the lady, they are already in love. After the search, both families especially the lady's family will make inquiries to know what the outcome of the marriage will be.

\section{The Inquiry}

Inquiry was done either by the parents themselves or by engaging the services of an intermediary to approach the girl's family and vice versa. This is to find out any form of diseases, and anything else that could make the marriage unsuccessful, unproductive, or a liability to the family. If the results of these inquiries were unfavourable, the girl's parents would not say so directly, but they would consult the Ifa priest who would tell the parents of the young man that the divination was unfavourable, and that would end it all. If the family was acceptable, this response would be communicated through an intermediary, and the agreement was sealed by payment of the ijohen. This is a gift from the man's family to the girl and the first instalment of the bride's wealth (Akinloye 1999). After the findings had been done, and favourable answer was received they will then proceed to the next stage which is the introduction.

\section{The Introduction Ceremony}

The introduction takes place at the bride's house. This is necessary for the groom's family to formally introduce themselves to the lady's family and also make known their intention of asking for their daughter's hand in marriage. The groom's family will come with a bottle of schnapps to be used for prayers for happy relationship between the two families and their children. The families will later agree on a date for the engagement which is the idana in Yoruba custom. The bride's family will entertain their guests and gift will be given to the bride.

\section{Engagement Ceremony (Idana)}

The Yoruba traditional marriage entails some customs which are adhered to few days to the traditional marriage. This includes taking the bride-to-be to the fattening room where she is well fed and also taught how to be a good wife. Engagement ceremony was and still remains an important part of the wedding ceremony in Yoruba culture (Gesinde, 2010). This is because traditionally, a couple is married after the engagement ceremony (Boomie, 2010). It is during the traditional marriage that the family of the bride and groom are introduced to each other for the second time (Gesinde, 2010). The attendees of this programme include: the parents of the bride and the groom, their extended families, the bride and the groom, their siblings, friends and wives of the two families.

The groom's family is given a list of items to be purchased and brought to their in-law's house. These items may be divided into two, the ones for the bride and that of the family. The items include:

\begin{tabular}{|c|c|l|}
\hline S/N & Bride's Items & \multicolumn{1}{|c|}{ Family's Items } \\
\hline 1 & Wrist watch & Yam 21 pieces \\
\hline 2 & Umbrella & Alligator pepper ataare 21 pieces \\
\hline 3 & Box & Bitter cola \& Colanut 21 pieces each \\
\hline 4 & Shoe & Oyin, aadun, Ireke, iyo \\
\hline 5 & Bag & Schnapps \\
\hline 6 & Cloths & Keg of Palm wine \\
\hline
\end{tabular}




\begin{tabular}{|c|l|l|}
\hline 7 & Headties & Dowry N42.00. \\
\hline 8 & & Owo iya gbo baba gbo N 2.10k \\
\hline 9 & & Owo omoile N2.00. \\
\hline 10 & & Owo iyawo ile N2.00. \\
\hline 11 & & Owo isigba N2.00. \\
\hline
\end{tabular}

In the Yoruba traditional setting, these are the most needed symbolic items, especially the food items that must be brought to the bride's family otherwise the ceremony will not hold. These items are used to pray for the bride and the groom by the bride's family. The dowry (owo-ori-iyawo) goes to the bride's parents to compensate them for some of the costs of raising the bride. It should be noted that much is not demanded from the man as it is being done nowadays. It is also important to note that these materials differ from one geographical location to another in Yoruba land (richard4real55, 2010). If it was revealed that they should not make much noise about the marriage, the bride will go with her husband's family after the engagement ceremony otherwise, a date will be fixed for the bride to go to her husband's house.

\section{Marriage Ceremony}

The marriage ceremony is always a glamorous affair. According to (Moshood, 2011) foods and palm wine are always in surplus, music and fun fair will fill the atmosphere both in the young man's house and the ladies' house. This ceremony is usually preceded by the "Bride's Eve (Àisùn llyàwó)" or "Bride's Enjoyment (Fàáji liyàwó)" (Barber 1991; 1994) where the major context of performance of the nuptial poetry (Ewì Ajemónáwó)( Ajibade, 2005) takes place. The bride will be chanting the nuptial chant known as ekun iyawo to receive blessings from her parents. Barber (1994) also confirmed that on the day before the girl moves into her husband's house, she makes a ceremonial tour around the town, starting with her own compound, saying farewell to her kin and announcing her impending change of state.

After this admonition and prayers from the family, the wives from the bride's husband's family, wives from the bride's family and some of her friends will take her to her new house with singing and dancing. As soon as the people from the lady's family begin to approach the house of the husband to be, the husband must leave the house as it is a taboo for the newly wedded wife to meet her husband at home. At the husband's house, before the bride enters the house, her feet will be washed with water in order to bring success, peace and tranquillity into the house. Immediately she enters her husband's house, she will be taken to the eldest person in the husband's family for the person's prayer (Ogundoro, 2007).

On that night, the first copulation will take place to confirm if she is a virgin or not. If the lady is found not to be a virgin, the young man might reject her and send her back to her parents in disgrace or decide anything about her case but those who follows the lady to her husband's house will be the one who will go and inform the lady's parent at home. It is expected in the olden days that all marrying ladies must be virgin. The family of the husband will now send half filled palm wine jar along with coal and empty match box to the lady's parent to denote that they have given them a used or empty girl to marry i.e. korofo ni omo ti e fun mi. This act brings ridicule and shame on the family of the lady. If on the other hand, the lady is a virgin, those who followed her to her husband's house will still be told the result and they will take the good tidings to the lady's parent at home with a calabash filled with fresh palm wine and a matches box filled with matches sticks. After the wedding, the next thing being expected is for the wife to conceive and give birth after nine months because the Yorubas' believe so much in having children.

\section{Social Change in Nigeria}

The term social change is used to indicate the changes that take place in human interactions and interrelations. Society is a web of social relationships and hence social change means change in the system of social relationships. Also, social change is a social process whereby the values, attitudes, or institutions of society become modified. It is a shifting of societal norms, which indicates that an entire society has adopted and applied a new behaviour or way of thinking (Fitzpatrick, nd). Norms are the agreed-upon expectations and rules by which a culture guides the behaviour of its members in any given situation.

Therefore social change is a significant alteration over time in behaviour patterns and cultural values and norms (Wiley, 2000). According to Murdock (1961 in Shackman and Wang, 2002) culture is a system of collective habits. The collective habits may be habits of actions, i.e., customs, or habits of thoughts, i.e., collective ideas. These habits are learned collectively. Some of the habits, for example marriage norms may be shared throughout the society, while others 
may be limited to certain classes or groups. If the situation of the society changes, old behaviour patterns may be discouraged and new patterns are encouraged.

\section{Causes of Societal Change in Nigeria}

The causes of societal change may be categorized into three headings. These are economic, political and cultural (Leat, 2005). Economic factors are determined by the societies or forms of social organizations as it deals with industrial capitalism. For the political factors, the state and the government played a significant role in the social life and change in industrial societies. Cultural influences also play a major role in social change (Giddens and Duneier, 2000).

Civilizations and education, brought by the British colonialist ushered in a drastic change in Yoruba marriage norms. Children, who are matured enough to marry, no longer allow their parents to choose a befitting partner for them. They make relationship with whoever they felt is the best that suit them and who they agreed to live with, for the rest of their life. As soon as the parties concerned meet themselves, agreed and ready to marry each other, the next thing is for the parents of the young man to meet the parents of the lady to introduce themselves very well (Akinbolaji, 2009).

The discovery of oil accelerated the changes and helped shape rapid socio-economic change and some aspect of Nigerian social life especially the marriage institution. The oil boom led to the assigning of substantial sums of money to the cocoa industry of southwestern Nigeria and many people became affluent. The sudden increase of wealth has greatly affected the Nigerian family. Urban areas in Nigeria are full of modern houses with western architectural designs and fences to keep out strangers. As a result people begin to showcase their wealth especially in marriage ceremonies.

Other factors that aided this change include western education, going to abroad for further studies, and exposure to various types of mass communication - television, video programmes, and satellite dishes. This brought about an increase in the number of educated men and women, and cultural contact with the Western world. The knowledge and information acquired through western education often lead the parents to soften their holds over their children because of the upliftment on socio-economic status. (Al-Khateeb, nd).

Also, as children start to work and earn wages, they contribute substantially to their family economic resources which in turn make parents listen and respect their children's ideas. The ripple effect of this is that children are given the opportunity to make more independent decisions about their life in general to choose their marriage partners in particular. Caldwell (1982) argues that Power in economic decision-making usually means power in demographic decision making.

As a result of the socio-economic change in the country, children no longer consulted their parents to find a befitting wife or husband for them in Yoruba land. Children of marriageable age, that is 18 years and above, do not wait for their parents, or any member of the community to choose for them instead they choose whoever they wanted to marry and agree to live with for ever themselves. Hence, the services of an intermediary are no longer sought for; instead the groom and the bride would be communicating through letters, phone calls, telegraphs, telex and fax. People using these forms of communication have money to spend and showcase their wealth.

The use of technology has even made it possible to find a wife for somebody in America by mere sending his photograph and then communicate on phones. In fact, there are some people around now whose business is to find wife or husband for those in need. They are called 'The match-makers'. People contacted them and get paid once the contract had been executed.

Most current-day weddings in Nigeria follow western processes which are referred to as modern marriages. Modern marriage institutions are time-honoured on policies that are increasingly mimicking western models where some indigenous cultures are often overlooked. Such marriage institutions are established by forces external to the community and characterized by functional and structural arrangements that are fairly standard and reflect specific image of western development (Enwereji, (2008).

Both the introduction and engagement ceremonies are no more parents' prerogatives. The families introduced themselves during the introduction ceremony but in this contemporary world of ours, surrogate parents are sometimes used by either of the people concern. This is not done for free but on contract. As a result of happenings in the society, both parties employ the services of an anchorage known as Alaga ljoko (sitting chair person) for the bride's family and Alaga Iduro (standing chair person) for the groom's family or Master of Ceremony in plain English, for a certain amount of money during the introduction and engagement ceremonies. The ceremonies are conducted by the Alaga ljoko and Alaga Iduro. It is Alaga ljoko who will start the programme with prayers. 
Fig. Alaga ljokoo - The Enigma at Yoruba Traditional Weddings, nairaland.com

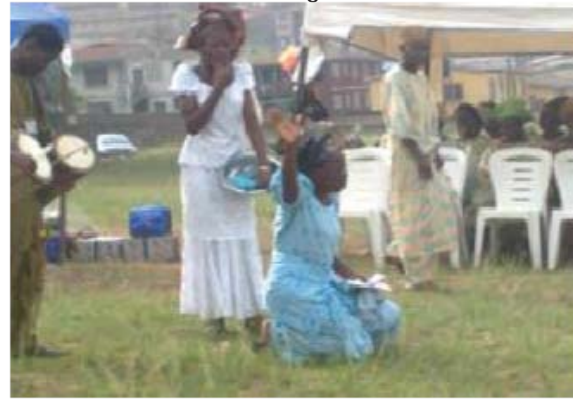

Source: Google images

It is also the sitting and standing chair persons that will introduce the families from both sides, a role meant for a member of the families. The families are just onlookers.

Fig. Alaga Iduro introducing the groom's family, Traditional Wedding, bellanaija.com

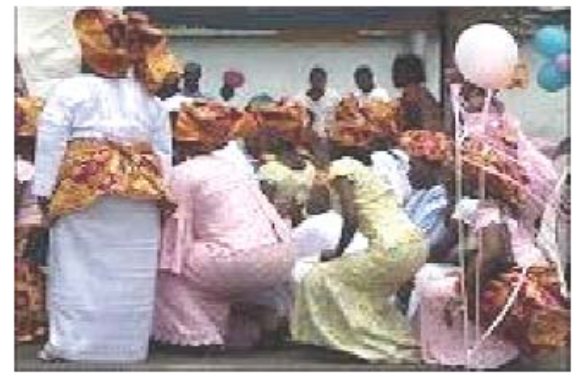

Source: Google images

The engagement ceremony is supposed to take place at the bride father's house but today the socio-economic change in the society has brought a change to this. Before the day of engagement, the bride's father will scout round for big venue either a hall or an open space which would be lavishly decorated in order to show that the bride's father is affluent.

Fig. Engagement Venue

Source: Google images

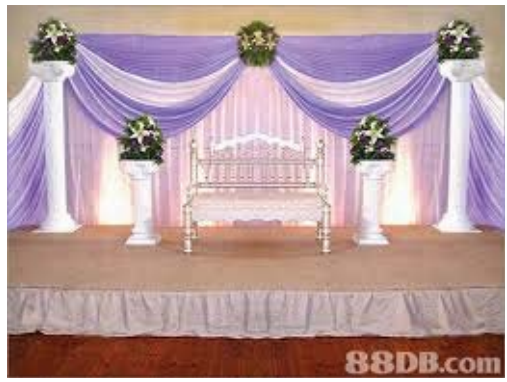

Another changes noticed during engagement is the quick match introduced by the Alaga ijoko. The groom and his friends will be ordered by the Alaga ijoko to quick match, stand at alert before prostrating to greet the bride's family and beg for their permission to marry their daughter. 
Fig. The groom and his friends prostrating, artsyswag.com

Source: Google images

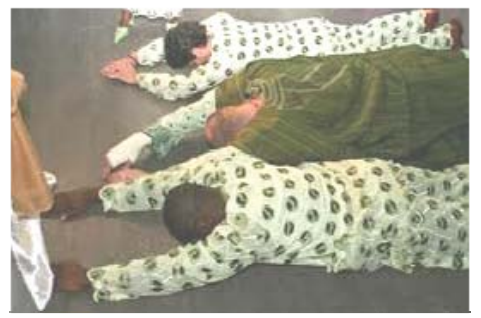

There is also a drastic change in the list of items brought to the bride's family by the groom's family. The list of items is tabulated below:

\begin{tabular}{|c|c|}
\hline Bride's Items & Family's Items \\
\hline Umbrella & Yam 42 pieces \\
\hline Engagement Ring & Alligator pepper (ataare) 42 pieces \\
\hline Gold Wrist Watch & Bitter cola \& Colanut 42 pieces each \\
\hline 2 Different Pairs of Shoes and Bags & Ireke and assorted fruits \\
\hline 2 Head Gears (of high quality & 2 bottles of Schnapps \\
\hline 1 Traditional Cloth (Aso- Oke) & 1 bag of salt \\
\hline 4 Other Assorted Clothes & 42 pieces of Big Eja Osan (Dry fish) \\
\hline One Big Suitcase & 1 Decanter of Pure Honey \\
\hline \multirow[t]{25}{*}{ Engagement Bible } & 1 Big Dish of Aadun (peppered Corn meal) \\
\hline & 1 Big Dish of Sugar \\
\hline & 4 Cartons of Five Alive \\
\hline & 4 Crates of Can Drinks \\
\hline & 6 Bottles of Wine \\
\hline & 2 Crates of Can Malt \\
\hline & 1 Bag of rice \\
\hline & $1 \mathrm{Keg}$ of Palm oil \\
\hline & $1 \mathrm{keg}$ of Groundnut oil \\
\hline & 1 Big She-goat \\
\hline & 1 big Fowl \\
\hline & Dowry $10,000.00$ \\
\hline & Owo iya gbo baba gbo (bride's parent's consent) $\$ 5,000.00$ \\
\hline & Owo omoile okunrin (all male children) $\$ 1000.00$. \\
\hline & Owo omoile obinrin (all female children) 1000.00 . \\
\hline & Owo iyawo ile (wives in the family) $1,000.00$. \\
\hline & Owo isigba (to open the items on the list) $\$ 500.00$. \\
\hline & Owo ljoko Agba (elders in the family) - 1,000 \\
\hline & Owo ljoko lyawo (to bring in bride) - 1,000 \\
\hline & Owo Isiju lyawo (unveiling the bride) 1,000 \\
\hline & Owo Isilekun (Entrance fee) 500 \\
\hline & Owo Phone (money for phone calls) 500 \\
\hline & Owo Plane (money for travel to groom's family house)- 500 \\
\hline & Reading of Letter - 500 \\
\hline & Owo Alaga ljoko (money for MC) - 500 \\
\hline
\end{tabular}

The groom's family is expected to bring these items listed for them to the bride's family. Failure to bring every item on the list attracts a fine or a penalty. 
Picture: Items for Traditional Wedding in Yoruba land, motherlandnigeria.com/pictures

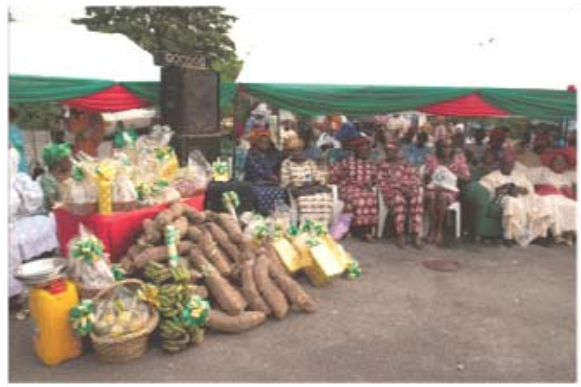

Source: Google images

The articles of prayer such as: kolanut, alligator pepper, bitter kola, honey etc, were used by the elderly person in the family to pray for the bride and the groom but in this contemporary world, the Alaga ljoko performs the function of using these articles to pray for the bride and the groom. Those who are supposed to perform the function have become audience at the ceremony.

By the evening period, the lady's mother will call her daughter and advice her on how to behave and live her life in her husband's house. Thereafter the eldest person in the family calls her to pray for her before giving her a departing gift. After this admonition and prayers, her family members and her friends will see her off with singing and dancing to her new home. Today things have changed. The bride goes with her husband in her white garment immediately after the reception without going back to her father's house for their parting word of advice and prayers.

The socio-economic change has also affected the obligations of the would-be-husband to his in-laws. In the past, the would-be husband takes care of his wife-to-be in different ways. Apart from buying gift items for the wife whenever there is a ceremony in the wife's family, the man's family will bring gifts items like money and food items such as yam, meat, palm wine etc, to the in-law's house to celebrate with them. Also, when it is time to cultivate land for farming, the would-be-husband will seek for the help of his friend to work on his in-law's farm. This practice is known as (òwè) in Yoruba culture. These practices aimed at solidifying and maintaining cordial relationship between the two families have become the thing of the past. Inter tribal marriages, distance and the types of jobs the man engages in have affected these practices in no small measure.

According to Ajibade (2005), marital sanctity and pre-marital sanctity have much value among the Yoruba. This is because it is a thing of honour, glory and pride for the parents of bride as well as the unmarried lady for keeping her virginity until the time of marriage. In fact, gifts are associated with it. The bride's friends sing songs to praise the bride once they have the assurance that their friend, the bride, is still a virgin.

For example one of those songs is:

$\begin{array}{ll}\text { O yege - } & \text { You have passed } \\ \text { Ayókúnnu o yege - } & \text { Ayókúnnu, you have passed } \\ \text { Kólá rí o lómoge - } & \text { Kólá has seen you as a virgin } \\ \text { Ó si gbé o níyàwó - } & \text { And has taken you as his wife } \\ \text { Ayókúnnu, o yege - } & \text { Ayókúnnu, you have passed. }\end{array}$

If on the other hand, it was discovered that the bride had lost her virginity before the marriage, they may also sing to abuse and mock her for the loss of her virginity. This they do to correct and also warn others who are yet to marry to keep their virginity until marriage ( Ajibade, 2005):
İbálé kì fò -
Virginity does not fly
Ki lo mú tìe şe? -
What have you done with your own?

The bride should be a virgin before the actual wedding, but today things have changed. The socio-economic change in the society has grossly affected the culture of keeping virginity in marriage. Sexual dealings have become games. Those who are keeping their virginity are regarded as anti-social, especially in the mist of their friends. As a matter of fact the couples usually want to ensure that they can have children, so, the bride could be pregnant before the 
wedding or already have children.

\section{Conclusion}

This paper on the influence of socio-economic change on marriage norms in the Yoruba society in southwest Nigeria has shown that the predominant family orientation has changed from the extended institutional family to the small selfcontained modern family. It also shows that marriage institutions are established by forces external to the community as a result of socio-economic change experienced in the society. Also, it shows that African weddings include a lot of music by rhythmical drums, rich of colours and people are happy, cheering and clapping. This is something that has always existed both in the Western society and the African society and this will hopefully never change.

\section{Reference}

Ajibade, G. O.( 2005). Is there no man with penis in this land? Eroticism and performance in yoruba nuptial songs. African Study Monographs, 26(2): 99-113

Akinbolaji, T. J,( 2009). Marriage culture in Yorubaland, Nigeria, Africa http://www.helium.com/items/1320012-how-the-yorubas-valuedmarriage-in-thier-society

Akinloye, Ojo (1999). Yoruba People, Language, and Culture. Yoruba Language Program Students. University of Georgia.

Barber, K. 1991. I Could Speak until Tomorrow: Oríkì, Women and the Past in a YorùbáTown. University Press, Edinburgh

Barber, K. (1994). Polyvocality and the individual talent: Three women Oríkì singers in Òkukù. In (R. Abiodun, H.J. Drewal \& J. Pemberton III, eds.) The Yoruba Artist: New Theoretical Perspectives on African Arts, pp. 151, ff. Smithsonian Institution Press, Washington \& London.

Boomie O.(2010). Marriage \& Family http://www.motherlandnigeria.com/life.html

Caldwell, J.C., and P. Caldwell. 1977. "The Economic Rationale of High Fertility: An Investigation Illustrated with Nigerian Survey Data." Population Study 31: $5-27$

Caldwell, J. C. (1982). Theory of Fertility Decline. London: Academic Press.

Al-Khateeb, S. (nd) The Oil Boom and its Impact on Women and Families in Saudi Arabia

CliffsNotes.com. (2010) Cultural Norms. <http://www.cliffsnotes.com/study_guide/topicArticleld-26957,articleld-26853.html>.

CliffsNotes.com. (2010). Culture and Society Defined. 3 Jun 2010 http://www.cliffsnotes.com/study guide /topicArticleld-26957,articleld26848.html

Dizard, J.E., and H. Gadlin, 1990. The Minimal Family. Amherst, Mass.: University of Amherst Press

Elkind, D. 1992. The Post-modern Family, A New Imbalance. New York: Knopf.

Enwereji, E. E (2008). Indigenous marriage institutions and divorce in Nigeria: the case of Abia state of Nigeria. Eur J Gen Med. 5(3):165-169

Fitzpatrick, L., (nd). Social Change Theory Social Change Theory | eHow.com http://www.ehow.com/about_5462601_social-changetheory.html\#ixzz1qW8mUjMn

Gesinde , T. (2010). Wedding: Doing it the traditional way! http://tribune.com.ng/sun/conjugal-affairs/2261-wedding-doing-it-thetraditional-way

Giddens,A. and Duneier,M. ( 2000). Introduction to Sociology (3rd edition), New York and London: W.W.

Lasch, C. 1977. Haven in a Heartless World. New York: Basic Books.

Leat, D. (2005). Theories of Social Change http://www.peecworks.org/PEEC/PEEC_Inst/017962C6-001D0211.0/Leat\%202005 \%20Theories_of_change.pdf

Moshood, H.O. (2011). Traditional Marriage Ceremony in Yoruba Culture, Folk Magazine.

Ngwa, C. A. (2003). Development authorities as agents of socio-economic change: an historical assessment of the upper nun valley development authority (unvda) in the ndop region of cameroon, 1970-1995. Nordic journal of african studies 12(2): 220-237

Ogundoro, D. (2007). Marriage culture in Yorubaland, Nigeria, Africa. Helium inc.

Popoola, S., Oyesanya, F. (2008). Ikunle Abiyamo, the Ase Of Motherhood, 1st ed. Asefin Media LLP

Quale, G.R. 1988. A History of Marriage Systems. Contributions in Family Studies, Number 13. New York: Greenwood.

Richard4real55,(2010) Yoruba Traditional Marriage

Stone, L. 1977. The Family, Sex and Marriage in England, 1500-1800. New York: Harper and Row.

Shackman, G. L. L and Wang, G. (2002). Why does a society develop the way it does? http://gsociology.icaap.org/report/summary2.htm Social Change Theory | eHow.com http://www.ehow.com/about_5462601_social-change-theory.html\#ixzz1qVwOEQuY

Wiley, J. (2000). Social change http://www.cliffsnotes.com/study_guide/Social-Change-Defined.topicArticleld-26957,articleld-26951.html 